Article - Biological and Applied Sciences

\title{
Impact of Anthropogenic Activities on Water Quality of The Paranhana River, Southern Brazil
}

Thaís Dalzochio ${ }^{1 *}$

https://orcid.org/0000-0003-1095-9111

Mateus Santos de Souza ${ }^{1}$

https://orcid.org/0000-0001-9892-1905

Leonardo Airton Ressel Simões ${ }^{1}$

https://orcid.org/0000-0002-3471-6758

Gláucia Joselaine Herbert Silva ${ }^{2}$

https://orcid.org/0000-0002-8970-0868

Gabriela Zimmermann Prado Rodrigues ${ }^{1}$

https://orcid.org/0000-0002-8580-6243

Natália Bordin Andriguetti ${ }^{2}$

https://orcid.org/0000-0002-0077-1468

Luciano Basso da Silva ${ }^{3}$

https://orcid.org/0000-0002-9501-3802

Günther Gehlen 1

https://orcid.org/0000-0001-6308-4721

1 Universidade Feevale, Comparative Histology Laboratory, Novo Hamburgo, RS, Brazil;

2 Universidade Feevale, Toxicological Analyses Laboratory, Novo Hamburgo, RS, Brazil;

${ }^{3}$ Universidade Feevale, Animal Cytogenetics Laboratory, Novo Hamburgo, RS, Brazil.

Received: 2018.09.25; Accepted: 2019.07.08.

*Correspondence: tdalzochio@gmail.com; Tel.: +55 54981430668 (T.D.)

\section{HIGHLIGHTS}

- High levels of some water parameters were found at both sampling sites.

- Higher genotoxic potential was found in fish from the source of the river.

- Gill histopathological alterations were found in fish from both sites.

- Levels of some metals in fish muscle were above the limits for safe human consumption. 
Abstract: The Paranhana River, located in Southern Brazil, is one of the major tributaries of the Sinos River basin and receives mainly industrial and domestic effluents. In the present study, water physicochemical and microbiological analyses, condition factor, micronucleus test, gill histopathology and metal bioaccumulation in the muscle of the native fish Bryconamericus iheringii collected at two sites (S1 and S2) of the Paranhana River under different degrees of anthropogenic pressures were assessed in four sampling campaigns. Data from water quality parameters, condition factor, mucous cells proliferation in fish gills and bioaccumulation of chromium and manganese in muscle evidenced higher impacts at S2, whereas a higher genotoxic potential was observed at S1. Gill histopathological alterations were found in fish captured at both sampling sites. Temporal variations in all biomarkers analyzed and bioaccumulation of manganese and nickel were observed at $S 1$, whereas only variations in condition factor, gill alterations and bioaccumulation of manganese and aluminum were found at S2. Our study evidences that $\mathrm{S} 1$ is under minor anthropogenic impacts and that the high urbanization at $\mathrm{S} 2$ reflects in a poor water quality. Nonetheless, the human consumption of fish from the Paranhana River should be avoided given the high concentrations of cadmium, chromium and lead.

Keywords: biomarkers; Paranhana River; bioaccumulation; histopathology; micronucleus.

\section{INTRODUCTION}

Discharges of industrial, domestic and agricultural contaminants into water resources, combined to the elimination of riparian vegetation, erosion, terrestrial runoffs, irregular landfills, and so forth, contribute to the poor water quality and loss of biodiversity [1]. Hence, there is a need to use early warning signs of impairment to assess the health of aquatic ecosystems.

The use of biomarkers in fish, combined to water physicochemical analyses and metal bioaccumulation in tissues, constitute in an important approach to assess water quality [2-4]. Fish play a major ecological role in aquatic food webs as carriers of energy from lower to higher trophic levels [5-8]. Among other biomarkers, morphometric indices, the micronucleus (MN) test and gill histopathology evaluation are the main biomarkers used to assess the health of aquatic ecosystems in Brazil [9]. Another important aspect to be considered in the biomonitoring of water resources is the metals bioaccumulation, given their toxicity, persistence and their potential of biomagnification [10].

The Bryconamericus genus belongs to the Characiformes order and includes small-sized species presenting omnivorous behavior [11]. The Bryconamericus iheringii (Boulenger, 1887) occurs in Brazil, Uruguay and Argentina [12] being widely distributed in the Sinos River basin [13].

The Paranhana River is located in the middle section of the Sinos River basin and is one of the main tributaries of the Sinos River. The Paranhana River drains an area of $575 \mathrm{~km}$ [14], representing $16 \%$ of the basin. The main industrial activities in the area are based on leather confections, footwear, beverages and agricultural activities (mainly cattle breeding) [14]. However, municipalities near the river do not count on domestic sewage treatment. So far, most studies have focused only on the Sinos River, evidencing its poor quality using a variety of bioindicators, but studies on the Paranhana River are still scarce. Thus, this study aimed to biomonitor the water quality of the Paranhana River using different biomarkers and metal detection in native fish, combined with water physicochemical and microbiological analyses.

\section{MATERIAL AND METHODS}

The Paranhana River is located in the lower part of the Northeastern Slope, at the south boundaries of the Serra Geral (a major mountain range in Southern Brazil) in Rio Grande do Sul state, with altitudes varying from $20 \mathrm{~m}$ to $773 \mathrm{~m}$. The Paranhana River has its source formed by small streams and also receives water from the Caí River basin $\left(11.6 \mathrm{~m}^{3} / \mathrm{s}\right)$ through the water transposition from the Salto, Divisa and Blang dams. The river waters flow 
into the Sinos River - considered as the fourth most polluted river in Brazil [15]. Two sampling sites were selected in the Paranhana River (Fig. 1). Site 1 (S1) is located in Três Coroas municipality near the source of the river $\left(29^{\circ} 25^{\prime} 29.39^{\prime \prime} S\right.$; $\left.50^{\circ} 46^{\prime} 17.05^{\prime \prime} \mathrm{W}\right)$ and upstream the urban area, $8 \mathrm{~km}$ downstream the Caí river water transposition. The local is used for recreational purposes, especially in the summer. Site 2 (S2) is located in Taquara municipality near the mouth of the river, approximately $38 \mathrm{~km}$ downstream S1 and $4 \mathrm{~km}$ upstream the local where the river flows into the Sinos River. The potential sources of pollution at this site include the domestic sewage and industrial effluents from the municipalities previously mentioned.

Four sample collections of water and fish specimens were conducted in April (autumn), July (winter), and December (spring) of 2014 (Apr/14, Jul/14 and Dec/14) and March (summer) 2015 (Mar/15). Water samples were collected, transported, stored and analyzed according to recommendations of Standard Methods for the Examination of Water and Wastewater [16]. The following parameters were analyzed: biochemical oxygen demand $\left(\mathrm{BOD}_{5}\right)$, chemical oxygen demand (COD), total phosphorus, ammoniacal nitrogen, total suspended solids, total and thermotolerant coliforms, aluminum, copper, iron, lead, total chromium and zinc. The results were analyzed according to the CONAMA Resolution $357 / 2005$ for class 1 waters - water intended to human consumption after simplified treatment, recreational purposes and protection of aquatic communities [17].

Specimens of $B$. iheringii were collected using fish traps and nets. In the field, fish were weighed and measured, then sacrificed by medullar sectioning and blood samples were immediately taken via caudal vein to obtain blood smears. Gills were removed and fixed in Bouin solution, while muscle was also sampled, stored in ice and then kept under $-20^{\circ} \mathrm{C}$ until analysis. This study was approved by the Ethics Committee for Animal Experimentation of Universidade Feevale (protocol n. 02.13.022) and fish collections were authorized by the Brazil's federal environmental protection agency (SISBIO n. 40376-2). Additionally to water and fish samplings, data on local rainfall were obtained from a meteorological station located

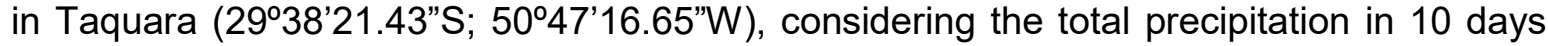
prior to each collection at each site [18].

The relative condition factor (CF) was calculated for all fish following the equation: $\mathrm{CF}=$ 100 (BW/L3), where BW = body weight $(\mathrm{g})$ and $\mathrm{L}=$ total body length $(\mathrm{cm})$ [19]. For the $M N$ test, blood samples were smeared onto microscopic slides, fixed in absolute ethanol and stained with Giemsa 5\% (NewProv). The slides were coded and a total of 3000 erythrocytes was analyzed for each fish using optical microscopy. Micronuclei identification followed the criteria: MN should be small, non-refractive, circular or ovoid chromatin bodies presenting the same staining pattern as the main nucleus [20]. Other nuclear anomalies in peripheral erythrocytes, as invaginations, buds and binucleated cells were scored and grouped as nuclear abnormalities (NA) [21]. For histopahological analysis, after fixation, gills samples were dehydrated and embedded in paraffin. Samples were then sectioned $(5 \mu \mathrm{m})$ using a

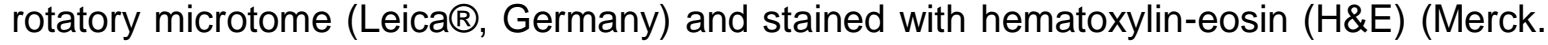
Darmstadt, Germany) and with Periodic Acid Schiff (PAS) - for the identification of mucous cells. The analyses were performed using optical microscopy according to the protocol previously described [22].

The dry washing method was performed to determine concentrations of aluminum, cadmium, chromium, lead, manganese, nickel and zinc in fish muscle [23]. For processing, samples were weighed and approximately $0.25 \mathrm{~g}$ of muscle per animal was used. Samples were digested in a solution of $10 \% \mathrm{NH}_{4} \mathrm{NO}_{3}$ (Sigma-Aldrich ${ }^{\circledR}$ ), using a ratio of $2 \mathrm{~mL} / \mathrm{g}$ of sample. Then, they were dried at $110^{\circ} \mathrm{C}$ for two hours. Samples were then calcined at $500^{\circ} \mathrm{C}$ for two hours and the ashes were mixed with 1 to $2 \mathrm{~mL}$ of $65 \% \mathrm{HNO}_{3}$ (Merck. Darmstadt, Germany) using a ratio of $2 \mathrm{~mL} / \mathrm{g}$ of sample. The samples were dried at $500^{\circ} \mathrm{C}$ again for two hours and the residues were treated with $10 \mathrm{~mL}$ of $0.1 \%$ Triton (Baker Analyzed®) and $1 \%$ $\mathrm{HNO}_{3}$. Samples were analyzed using a Perkin Elmer Analyst 600 graphite furnace atomic absorption spectrometer (GFAAS), following standard procedures according to each metal. Muscle samples of fish collected in Jan/14 were not obtained. Metals concentrations in fish muscle were compared to the limits considered safe for human consumption, according to the National Health Surveillance Agency (Agência Nacional de Vigilância Sanitária) [24,25]. 
Data of biomarkers responses were analyzed using the Mann-Whitney and Kruskal-Wallis tests followed by the Dunn's multiple comparisons test. Metals concentrations in fish muscle were analyzed using the Student's $t$ test and one-way analysis of variance (ANOVA) followed by the Tukey's posttest. The Spearman correlation analysis ( $r$ ) was used to verify the influence of precipitation in the biomarker's responses and metal concentrations in the water and in fish muscle. The reference values that classify the correlations were $0>r<0.3$ (weak), $0.3<r<0.6$ (moderate) and $r>0.6$ (strong) [26]. Significant differences were considered when $p \leq 0.05$. Data are expressed as mean \pm standard deviation.

\section{RESULTS}

Data from water physicochemical and microbiological parameters are summarized in table 1. The mean values of total phosphorus, iron and lead exceeded the limits at S1, whereas BOD5, total phosphorus, thermotolerant coliforms, aluminum, iron and lead exceeded the limits at S2. At S2, all water samples presented values of thermotolerant coliforms, iron and lead above the limits. In general, higher values were found at S2. Copper and total chromium were not detected in any sample, whereas ammoniacal nitrogen and aluminum were only detected at $\mathrm{S} 2$.

Table 1. Mean, standard deviation, minimum and maximum values of physicochemical and microbiological parameters of water samples collected at the source and mouth (S1 and S2, respectively) of the Paranhana River in four sampling periods.

\begin{tabular}{|c|c|c|c|c|c|c|c|}
\hline \multirow[t]{2}{*}{ Parameter } & \multirow{2}{*}{$\frac{\text { S1 }}{\text { Mean }}$} & \multicolumn{5}{|c|}{$\mathrm{S} 2$} & \multirow[t]{2}{*}{$\mathrm{RV}^{*}$} \\
\hline & & $\min$ & $\max$ & Mean & $\min$ & $\operatorname{Max}$ & \\
\hline $\mathrm{BOD}_{5} \mathrm{~A}$ & $1.5 \pm 1.7$ & n.d. & 3.0 & $7.3 \pm 10.6$ & n.d. & 23.0 & 3 \\
\hline $\mathrm{COD}^{\mathrm{A}}$ & $15.7 \pm 9.6$ & 10.0 & 30.1 & $12.9 \pm 8.1$ & 7.6 & 25.0 & - \\
\hline Total phosphorus ${ }^{B}$ & $0.15 \pm 0.09$ & 0.04 & 0.23 & $0.17 \pm 0.10$ & 0.08 & 0.31 & 0.1 \\
\hline Ammoniacal nitrogen $B$ & n.d. & & & $1.3 \pm 2.5$ & n.d. & 5.1 & 3.7 \\
\hline Total suspended solids ${ }^{B}$ & $5.7 \pm 2.4$ & 3.6 & 9.0 & $36.0 \pm 32.0$ & 8.2 & 69.8 & - \\
\hline Total coliforms ${ }^{\mathrm{C}}$ & $2271 \pm 1370$ & 980 & 4100 & $41257 \pm 23995$ & 24000 & 77010 & - \\
\hline $\begin{array}{l}\text { Thermotolerant } \\
\text { coliforms }^{C}\end{array}$ & $179 \pm 57$ & 97 & 231 & $9947 \pm 6225$ & 5200 & 17230 & 200 \\
\hline Aluminum ${ }^{B}$ & n.d. & & & $0.9 \pm 0.7$ & n.d. & 1.6 & 0.1 \\
\hline Copper ${ }^{B}$ & n.d. & & & n.d. & & & 0.009 \\
\hline $\operatorname{Iron}^{\mathrm{B}}$ & $0.6 \pm 0.3$ & 0.4 & 1.0 & $1.6 \pm 1.2$ & 0.7 & 3.1 & 0.3 \\
\hline LeadB $^{B}$ & $0.04 \pm 0.04$ & n.d. & 0.09 & $0.05 \pm 0.04$ & 0.02 & 0.10 & 0.01 \\
\hline NickelB & $0.002 \pm 0.004$ & n.d. & 0.008 & $0.006 \pm 0.007$ & n.d. & 0.015 & 0.025 \\
\hline Total chromium ${ }^{B}$ & n.d. & & & n.d. & & & 0.05 \\
\hline $\operatorname{Zinc}^{B}$ & $0.06 \pm 0.05$ & 0.03 & 0.13 & $0.06 \pm 0.01$ & 0.01 & 0.02 & 0.18 \\
\hline
\end{tabular}

${ }^{\mathrm{A}}$ expressed in $\mathrm{mg} \mathrm{O}_{2} \mathrm{~L}^{-1} ;{ }^{\mathrm{B}}$ expressed in $\mathrm{mg} \mathrm{L}^{-1} ;{ }^{\mathrm{C}} \mathrm{NMP} / 100 \mathrm{~mL}$. n.d.: not detected by the method. Detection limits: $\mathrm{BOD}_{5}: 5 \mathrm{mg} \mathrm{O}_{2} \mathrm{~L}^{-1}$; ammoniacal nitrogen: $5 \mathrm{mg} \mathrm{L}^{-1}$; aluminum: $0.5721 \mathrm{mg} \mathrm{L}^{-1}$; copper: $0.0107 \mathrm{mg} \mathrm{L}^{-1}$; lead: $0.0065 \mathrm{mg} \mathrm{L}^{-1}$; total chromium: $0.0106 \mathrm{mg} \mathrm{L}^{-1}$. *Reference values according to CONAMA resolution $357 / 2005$ for Class 1 waters. Mean values above the limits are highlighted in bold.

Fish captured at $\mathrm{S} 1$ in the four sampling periods weighed $10.41 \pm 0.72 \mathrm{~g}$ and the total body length corresponded to $9.00 \pm 0.17 \mathrm{~cm}$, whereas fish captured at S2 weighed $4.97 \pm$ $0.87 \mathrm{~g}$ and total body length corresponded to $7.16 \pm 0.22 \mathrm{~cm}$. Sample size, CF, MN and NA are presented in table 2. Fish collected at S2 in Dec/14 presented significant lower CF than fish collected at $S 1(p=0.044)$. A significant temporal variation in CF was observed at both sampling sites. At S1, fish collected in Apr/14 presented higher CF than fish collected in $\mathrm{Dec} / 14(\mathrm{p}=0.042)$. At S2, higher CF was found in fish collected in Apr/14 and Mar/15 in comparison to $\mathrm{Dec} / 14(\mathrm{p}=0.001)$. For $\mathrm{MN}$, significant differences between sites were only observed in Mar/15, when fish collected at S1 presented higher frequencies $(p=0.047)$. The frequencies of MN were higher in Mar/15 in comparison to Apr/14 and Dec/14 ( $p=0.003)$ at $\mathrm{S} 1$, whereas no significant temporal variation was observed at S2. Fish collected at S1 
presented significant higher frequencies of NA in Jul/14 and Dec/14 than fish collected at S2 $(p=0.022$ and $p=0.03$, respectively). Similar to $M N$, significant temporal variation in the frequencies of NA was only observed at $S 1$, where higher frequencies were observed in $\mathrm{Jul} / 14$ and Mar/15 in comparison to Apr/14 and Dec/14 $(p=0.046)$.

Table 2. Sample size (N), condition factor (CF), micronucleus (MN) and nuclear abnormalities (NA) frequencies in B. iheringii collected at two sampling sites (S1 and S2) of the Paranhana River in four sampling periods.

\begin{tabular}{lccccc}
\hline & Site & $\mathrm{N}$ & $\mathrm{CF}$ & $\mathrm{MN}^{*}$ & $\mathrm{NA}^{*}$ \\
\hline Apr/14 & $\mathrm{S} 1$ & 11 & $1.51 \pm 0.14^{\mathrm{aA}}$ & $0.03 \pm 0.09^{\mathrm{aA}}$ & $2.22 \pm 1.84^{\mathrm{aA}}$ \\
& $\mathrm{S} 2$ & 11 & $1.51 \pm 0.18^{\mathrm{aA}}$ & $0.00 \pm 0.00^{\mathrm{aA}}$ & $2.57 \pm 1.79^{\mathrm{aA}}$ \\
$\mathrm{Jul} / 14$ & $\mathrm{~S} 1$ & 12 & $1.43 \pm 0.19^{\mathrm{aAB}}$ & $0.18 \pm 0.15^{\mathrm{aAB}}$ & $5.92 \pm 3.82^{\mathrm{aB}}$ \\
& $\mathrm{S} 2$ & 12 & $1.28 \pm 0.17^{\mathrm{aAB}}$ & $0.08 \pm 0.21^{\mathrm{aA}}$ & $2.00 \pm 1.09^{\mathrm{bA}}$ \\
$\mathrm{Dec} / 14$ & $\mathrm{~S} 1$ & 10 & $1.33 \pm 0.14^{\mathrm{aB}}$ & $0.03 \pm 0.10^{\mathrm{aA}}$ & $2.77 \pm 2.13^{\mathrm{aA}}$ \\
& $\mathrm{S} 2$ & 7 & $1.18 \pm 0.17^{\mathrm{bB}}$ & $0.09 \pm 0.16^{\mathrm{aA}}$ & $2.14 \pm 1.77^{\mathrm{aA}}$ \\
$\mathrm{Mar} / 15$ & $\mathrm{~S} 1$ & 9 & $1.35 \pm 0.12^{\mathrm{aAB}}$ & $0.41 \pm 0.52^{\mathrm{aB}}$ & $5.59 \pm 3.74^{\mathrm{aB}}$ \\
& $\mathrm{S} 2$ & 12 & $1.22 \pm 0.17^{\mathrm{aB}}$ & $0.08 \pm 0.15^{\mathrm{bA}}$ & $2.28 \pm 1.59^{\mathrm{bA}}$ \\
\hline
\end{tabular}

${ }^{*}$ Frequencies expressed in \%. Means with different lower case letters are significantly different when comparing sampling sites in the same period. Means with different upper case letters are significantly different when comparing a sampling site in different periods.

Representative images of the histopathology analysis of gills are found in figure 2 and quantitative analysis of histopathology alterations is presented in table 3 . Lamellar alterations such as hypertrophy and hyperplasia of epithelial cells were the most frequent lesions found in fish collected at both sampling sites, whereas lamellar fusion and epithelial lifting were the less frequent. Fish collected at S1 presented significant higher frequencies of hyperplasia of epithelial cells and epithelial lifting in Jul/14 ( $p=0.006$ and $p<0.001$, respectively), whereas fish collected at S2 presented higher frequencies of hypertrophy of epithelial cells also in Jul/14 $(p<0.001)$. No significant spatial differences were observed in the frequencies of lamellar fusion, aneurysm and necrosis. A significant temporal variation in the frequencies of hypertrophy and hyperplasia of epithelial cells and epithelial lifting was observed. At S1, higher frequencies of hypertrophy were observed in Dec/14 and Mar/15 in comparison to Apr/14 and Jul/14 ( $p<0.001)$ and higher frequencies of hyperplasia were observed in Jul/14 in comparison to Dec/15 ( $p=0.048)$. Additionally, higher frequencies of epithelial lifting were observed in Jul/14 in comparison to other sampling periods $(p<0.001)$. At S2, higher frequencies of hypertrophy of epithelial cells were observed in Dec/14 and Mar/15 in comparison to other sampling periods $(p<0.001)$. No significant temporal variation was observed for other alterations.

Table 3. Frequencies of lamellar alterations (\%) in B. iheringii collected at two sampling sites (S1 and S2) of the Paranhana River in four sampling periods.

\begin{tabular}{llcccc}
\hline & & $\begin{array}{c}\text { Hipertrophy of } \\
\text { epithelial cells }\end{array}$ & $\begin{array}{c}\text { Hyperplasia of } \\
\text { epithelial cells }\end{array}$ & Lamellar fusion & Epithelial lifting \\
\hline $\mathrm{Apr} / 14$ & $\mathrm{~S} 1$ & $13.0 \pm 8.0^{\mathrm{aA}}$ & $2.3 \pm 2.6^{\mathrm{aA}}$ & $0.3 \pm 1.0^{\mathrm{aA}}$ & $0.0 \pm 0.0^{\mathrm{aA}}$ \\
& $\mathrm{S} 2$ & $14.7 \pm 8.0^{\mathrm{aA}}$ & $0.3 \pm 0.5^{\mathrm{aA}}$ & $0.3 \pm 1.0^{\mathrm{aA}}$ & $0.3 \pm 1.0^{\mathrm{aA}}$ \\
$\mathrm{Ju} / 14$ & $\mathrm{~S} 1$ & $1.2 \pm 2.0^{\mathrm{aA}}$ & $2.8 \pm 2.3^{\mathrm{aA}}$ & $0.0 \pm 0.0^{\mathrm{aA}}$ & $4.1 \pm 2.4^{\mathrm{aB}}$ \\
& $\mathrm{S} 2$ & $4.0 \pm 6.3^{\mathrm{bA}}$ & $0.0 \pm 0.0^{\mathrm{bA}}$ & $0.9 \pm 1.8^{\mathrm{aA}}$ & $0.0 \pm 0.0^{\mathrm{bA}}$ \\
$\mathrm{Dec} / 14$ & $\mathrm{~S} 1$ & $32.5 \pm 9.2^{\mathrm{aB}}$ & $0.3 \pm 0.7^{\mathrm{aB}}$ & $0.05 \pm 0.01^{\mathrm{aA}}$ & $0.4 \pm 0.9^{\mathrm{aA}}$ \\
& $\mathrm{S} 2$ & $46.1 \pm 7.1^{\mathrm{aB}}$ & $0.3 \pm 0.8^{\mathrm{aA}}$ & $0.0 \pm 0.0^{\mathrm{aA}}$ & $0.4 \pm 0.7^{\mathrm{aA}}$ \\
$\mathrm{Mar} / 15$ & $\mathrm{~S} 1$ & $37.5 \pm 10.7^{\mathrm{aB}}$ & $0.8 \pm 1.4^{\mathrm{aAB}}$ & $0.0 \pm 0.0^{\mathrm{aA}}$ & $0.3 \pm 0.5^{\mathrm{aA}}$ \\
& $\mathrm{S} 2$ & $43.8 \pm 9.6^{\mathrm{aB}}$ & $0.3 \pm 1.2^{\mathrm{aA}}$ & $0.0 \pm 0.0^{\mathrm{aA}}$ & $0.4 \pm 0.7^{\mathrm{aA}}$ \\
\hline
\end{tabular}

Different lower-case letters indicate significant difference between sites. Upper case letters indicate significant difference between sampling periods.

The frequencies of lamellae with alterations and mucous cells are presented in figure 3 ( $A$ and $B$, respectively). Significant higher frequencies of lamellae with alterations were 
observed in fish collected at S1 in Jul/14 ( $p=0.04)$. On the other hand, significant higher frequencies of lamellae with alterations were observed in fish collected at S2 in Dec/14 $(p=0.005)$. A significant temporal variation in lamellae with alterations was observed at both sampling sites, where fish collected in Apr/14 and Jul/14 presented significant lower frequencies of lamellae with alterations than fish collected in Dec/14 and March/15 ( $p<0.001$, for both sites). Considering mucous cells proliferation, significant higher frequencies were found in fish collected at S2 in Jul/14 and March/15 ( $p=0.02$ and $p=0.01$, respectively). A significant temporal variation was observed only at $\mathrm{S} 1$, where higher frequencies of mucous cells were observed in fish collected in Dec/14 in comparison to Jul/14 ( $p=0.03)$.

Metals concentrations found in fish muscle are presented in figure 4 . For aluminum, no significant difference was found between sites in all sampling periods, whereas a temporal variation was observed at $\mathrm{S} 2$, where significant higher concentrations were observed in Mar/15 in comparison to Jul/14 and Dec/14 ( $p=0.01$; Fig. 4A). Significant higher concentrations of chromium were observed in muscle of fish collected at S2 in Mar/15 $(p=0.02)$, whereas no significant temporal variations were found at both sampling sites (Fig. 4B). The mean concentrations of chromium exceeded the limits for human consumption $(0.1$ $\mu \mathrm{g} g-1$ ) in both sampling sites and all sampling periods. For manganese (Fig. 4C), significant higher concentrations were found at $S 2$ in Dec/14 $(p=0.004)$. For this metal, significant temporal variations were observed at both sampling sites. At S1, higher concentrations were observed in Apr/14 in comparison to Jul/14 and Dec/14; and in Dec/14 in comparison to $\mathrm{Jul} / 14(\mathrm{p}<0.001)$. At $\mathrm{S} 2$, significant lower concentrations of manganese were observed in $\mathrm{Jul} / 14(\mathrm{p}<0.001)$. Concentrations of nickel did not differ between sampling sites, however, a significant temporal variation was found at both sampling sites (Fig. 4D). At S1, higher concentrations of nickel were observed in Apr/14 in comparison to Jul/14 ( $p=0.04)$. At S2, higher concentrations were observed in Apr/14 and Dec/14 in comparison to Jul/14 and Mar/15 $(p=0.04)$. Values of nickel in fish muscle were within the limits for human consumption $(5.0 \mu \mathrm{g} \mathrm{g}-1)$. Significant spatial and temporal variations were not found in concentrations of cadmium (Fig. 4E), lead (Fig. 4F) and zinc. Zinc concentrations ranged from 10.5 to $15.0 \mu \mathrm{g} \mathrm{g}-1$ at $S 1$ and from 2.2 to $8.6 \mu \mathrm{g} \mathrm{g}-1$ at $S 2$ and did not exceed the limits for human consumption (50.0 $\mu \mathrm{g} \mathrm{g}-1)$ (data not shown). However, concentrations of cadmium exceeded the limits for human consumption $(0.05 \mu \mathrm{g} \mathrm{g}-1)$ at $\mathrm{S} 1 \mathrm{in} \mathrm{Jul} / 14$ and at $\mathrm{S} 2$ in Jul/14 and Mar/15. In addition, concentrations of lead were also above the limits $(0.3 \mu \mathrm{g}$ $\mathrm{g}-1)$ at $\mathrm{S} 1$ in Mar/15.

Similar precipitation data were recorded at both sites in all sampling periods, except for $\mathrm{Dec} / 14$, when a total of $59.2 \mathrm{~mm}$ was recorded at S1 and $81.2 \mathrm{~mm}$ at S2. Such difference may be attributed to the interval of three days between sampling collections. Total precipitation at both sites corresponded to 14.2, 38.5 and 57.1 in Apr/14, Jul/14 and Mar/15, respectively. The correlation analysis carried out between precipitation and other variables analyzed in the present study, revealed a significant strong negative correlation between precipitation and CF $(r=-0.817, p=0.01)$ and a strong positive correlation between precipitation and frequency of lamellae with alterations $(r=0.715, p=0.05)$.

\section{DISCUSSION}

The Paranhana River has an important role in the water availability for the Sinos River basin, being one of its main tributaries [14]. The results obtained by the present study for total phosphorus, thermotolerant coliforms, aluminum and lead at S2 classify the river as class 4 in a ranking of four classes (on a scale from one, indicating pristine conditions, to four, indicating heavily polluted), according to CONAMA resolution 357/2005 [17]. Class 4 waters are intended only to landscape harmony and navigation. Nonetheless, water is used for public supply, since a water treatment plant is located near this sampling site. The impact due to the lack of treatment of domestic sewage was more evidenced at S2, where high values of thermotolerant coliforms and $\mathrm{BOD}_{5}$ were found, which can be explained by the higher urbanization in this area. Thus, water quality of the Paranhana River decreases from S1 to S2 possibly as a result of higher urbanization.

In general, pollutants seem to have a negative effect on CF by reducing food availability and/or by increasing the energy required to maintain homeostasis [27]. In the present study, 
differences between sites were observed only in Dec/14, with fish from S2 exhibiting lower CF, which could indicate more environmental stress in this area during this period. In addition, the temporal variation in each site evidenced lower CF at both sampling sites in Dec/14, which could be related to the reproductive period of the species (spring and summer), when there is a depletion of energy reserves $[27,28]$ or to some unidentified factors with sporadic/occasional effect.

The genotoxic results evidenced occasional higher impacts at S1, despite the higher urbanization at S2. This fact might be attributed to the water transposition from the Caí River - where the main activities upstream the transposition are based on cattle farming and silviculture [29]. Chronic exposure to pollution may result in an acclimatization process with the subsequent decrease in organism susceptibility [30]. Significant temporal variation observed in both $\mathrm{MN}$ and $\mathrm{NA}$ frequencies at $\mathrm{S} 1$ may be attributed to variations in contaminants and also to natural causes, such as seasonality [31].

Histological alterations were observed in fish collected at both sites in all sampling periods, indicating environmental stress. Previous studies have demonstrated significant differences in gill alterations of fish captured at impacted and clean areas [32]. However, data obtained by the present study do not allow a clear discrimination between sampling sites according to land uses, suggesting that both sites are under some type of impact. The mucus secretion by mucous cells represents a defense mechanism against toxic substances [33]. Furthermore, the most frequent gill alterations in the present study, hypertrophy and hyperplasia of epithelial cells, are also recognized as defenses against the pollutants entrance in the bloodstream [34].

Metal concentrations in fish muscle were similar between sites, with exception of chromium and manganese, whose concentrations were significantly higher at S2 in one sampling period. These metals are linked mainly to leather tanning and agricultural practices, respectively, and also to rock erosion $[35,36]$. Thus, S2 seems to present some occasional environmental conditions that increase the uptake of these metals by the fish. In the Sinos River, chromium concentrations $\left(0.1\right.$ to $\left.0.6 \mu \mathrm{g} \mathrm{g}^{-1}\right)$ have been found in the liver of two fish species captured in the upper and lower sections of the river. Nonetheless, it is well known that higher concentrations of metals may be found in the liver since it is the main site of accumulation, biotransformation and excretion of pollutants in fish [23]. Temporal variations in metal concentrations were observed for aluminum, manganese and nickel. In general, lower concentrations were found in fish collected during the cold season (Jul/14). Similarly, previous studies have also reported lower metal content in cold seasons, being a reflection of lower feeding rate and respiratory rate during this period $[37,38]$. In addition to pollution, spatial and temporal variations in metal bioaccumulation may be a result of several factors such as sex, size, age, species and feeding behavior [39,40]. However, the influence of such variables in metal bioaccumulation was not assessed in the present study.

Concentrations of cadmium were above the threshold for safe human consumption [25] ( 0.1 and $0.05 \mu \mathrm{g} \mathrm{g}^{-1}$, respectively) at both sites in at least one sampling period, whereas lead was above the limits $\left(0.3 \mu \mathrm{g} \mathrm{g}^{-1}\right)$ at S1 in Mar/15. Chromium concentrations exceeded the limits $\left(0.1 \mu \mathrm{g} \mathrm{g}^{-1}\right)$ in all samples [24]. These metals are toxic and can pose health risks to humans, leading to gastrointestinal disorders, anemia, ulcers and so forth [41]. Data from our research group have also pointed to metals concentrations above the limits for safe human consumption in other sampling sites of the basin [22].

The precipitation plays an important role in the river dynamics. Rainfall may cause the dilution of pollutants present in water but also lead to surface runoff, providing a diffuse source of pollutants from agricultural (pesticides) and urban areas (oil, grease, polycyclic aromatic hydrocarbons and heavy metals) $[42,43]$. The negative correlation found between precipitation and CF suggests that pollutants from runoffs may impair nutritional status of fish and thus, decreasing the CF. However, there are no previous data in the literature indicating that precipitation of 10 days may significantly influence the CF. Furthermore, the positive correlation between precipitation and the frequency of lamellae with alterations also indicates that rainfall contributes to the transport of pollutant loads into the rivers and/or to the mobilization of contaminants present in the sediment. Nonetheless, this effect was not evidenced for other variables analyzed in the present study. 


\section{CONCLUSION}

In general, more severe damages were expected to be found in fish collected at S2, as a result of the higher urbanization and industrial activities. However, this study demonstrates that fish from both sites are under environmental stress, despite S1 is located in an area under minor anthropogenic disturbances. In addition, the variation in biomarker responses combined with metal bioaccumulation in fish muscle reflects the complex dynamics of biotic and abiotic factors in water resources. Thus, the development of monitoring studies to provide a diagnosis of the Paranhana River and to help in the improvement of water conditions for public supply should be encouraged. Furthermore, given the high concentrations of some metals in fish muscle, the consumption of fish from the Paranhana River should be avoided. Considering the water analyses, we suggest the Paranhana River contributes negatively to water quality of the Sinos River.

Funding: This work was supported by Fundação de Amparo à Pesquisa do Estado do Rio Grande do Sul-FAPERGS (scholarships), Universidade Feevale and Conselho Nacional de Desenvolvimento Científico e Tecnólogico (CNPq) (grant number 459718/2014-2). LBS is a CNPq researcher (308244/2015-0).

Conflicts of Interest: The authors declare no conflict of interest.

\section{REFERENCES}

1. Froehner S, Souza DB, Machado KS, Rosa EC. Tracking anthropogenic inputs in Barigui River, Brazil using biomarkers. Water Air Soil Poll. 2010; 201:33-41.

2. Fasulo S, Maisano M, Sperone E, Mauceri A, Bernabò I, Capello T, D’Agata A, Tripepi S, Brunelli E. Toxicity of Foroozan crude oil to ornate wrasse (Thalassoma pavo, Osteichthyes, Labridae): ultrastructure and cellular biomarkers. Ital J Zool. 2012;79(2):182-99.

3. Brandão F, Cappello T, Raimundo J, Santos MA, Maisano M, Maureci A, Pacheco M, Pereira P. Unravelling the mechanisms of mercury hepatotoxicity in wild fish (Liza aurata) through a triad approach: Bioaccumulation, metabolomic profiles and oxidative stress. Metallomics. 2015; 7:1352-63.

4. Maisano M, Cappello T, Oliva S, Natalotto A, Giannetto A, Parrino V, Battaglia P, Romeo T, Salvo A, Spanò N, Maureci A. PCB and OCP accumulation and evidence of hepatic alteration in the Atlantic bluefin tuna, Thunnus thynnus, from the Mediterranean Sea. Mar Environ Res. 2016; 121:40-8.

5. Van der Oost R, Beyer J, Vermeulen NE. Fish bioaccumulation and biomarkers in environmental risk assessment: a review. Environ Toxicol Pharmacol. 2003; 13:57-149.

6. Cappello T. Environmental metabolomics in aquatic pollution and toxicology. J Aquat Pollut Toxicol. 2018;2(1):22.

7. Parrino V, Cappello T, Costa G, Cannavà C, Sanfilippo M, Fasulo S. Comparative study of haematology of two teleost fish (Mugil cephalus and Carassius auratus) from different environments and feeding habits. Europ Zool J. 2018; 85:193-9.

8. Jafarabadi AR, Bakhtiari AR, Yaghoobi Z, Yap CK, Maisano M, Cappello T. Distributions and compositional patterns of polycyclic aromatic hydrocarbons (PAHs) and their derivatives in three edible fishes from Kharg coral Island, Persian Gulf, Iran. Chemosphere. 2019; 215:835-45.

9. Dalzochio T, Rodrigues GZP, Petry IE, Gehlen G, Silva LB. The use of biomarkers to assess the health of aquatic ecosystems in Brazil: a review. Int Aquat Res. 2016;8(4):283-98.

10. Campbell L, Verburg P, Dixon DG, Hecky RE. Mercury biomagnification in the food web of lake Tanganyika (Tanzania, East Africa). Sci Total Environ. 2008; 402:184-91.

11. Britski HÁ Sato Y, Rosa ABS. Manual de identificação de peixes da região de Três Marias, com chave e identificação para os peixes da bacia do rio São Francisco. 3rd ed. Brasília: Ministério da Irrigação - CODEVASF;1988. p.115.

12. Lampert VR, Azevedo MA, Fialho CB. Reproductive biology of Bryconamericus iheringii (Ostariophysi: Characidae) from rio Vacacaí, RS, Brazil. Neotrop Ichthyol. 2004;2(4):209-15.

13. Costa PF, Schulz UH. The fish community as an indicator of biotic integrity of the streams in the Sinos River basin, Brazil. Braz J Biol. 2010; 70:1195-205. 
14. Comitesinos - Comitê de Gerenciamento da Bacia Hidrográfica do Rio dos Sinos [Internet]. [place unknown: publisher unknown]; [updated 2009; cited 29 Jun 2009]. Available from: http://www.comitesinos.com.br/index.php?option=com_docman\&task=cat_view\&gid=25\&ltemi $\mathrm{d}=39$.

15. Instituto Brasileiro de Geografia e Estatística - IBGE. Indicadores de Desenvolvimento Sustentável - Brasil [Internet]. [place unknown: publisher unknown]; [updated 2010; cited 20 Dec 2016]. Available from: http://www.ibge.gov.br/home/geociencias/recursosnaturais/ids/default_2010.shtm.

16. APHA - American Public Health Association. Standard Methods for the Examination of Water and Wastewater. 21st ed. Washington (D.C.): APHA; 2005. 1220 p.

17. Brasil. Conselho Nacional de Meio Ambiente, resolução CONAMA 357, de 2005. [acesso em 2016 jun 6]. Available from: http://www.mma.gov.br/port/conama/res/res05/res35705.pdf.

18. Weather Underground [Internet]. [place unknown: publisher unknown]; [cited $2016 \mathrm{abr}$ ]. Available from:

https://www.wunderground.com/personal-weather-station/dashboard?ID=IRIOGRAN17.

19. Kerambrun E, Henry F, Cornille V, Courcot L, Amara RA combined measurement of metal bioaccumulation and condition indices in juvenile European flounder, Platichthys flesus, from European estuaries. Chemosphere. 2013; 91:498-505.

20. Al-Sabti K, Metcalfe C. Fish micronuclei for assessing genotoxicity in water. Mutat Res. 1995; 343:121-35.

21. Carrasco KR, Tilbury KL, Myers MS. Assessment of the piscine micronucleus test as an in situ biological indicator of chemical contaminant effects. Can $J$ Fish Aquat Sci. 1990;47(11):2123-36.

22. Dalzochio T, Simões LAR, Souza MS, Rodrigues GZP, Petry IE, Andriguetti NB, Silva NJH, Gehlen G, Silva LB. Water quality parameters, biomarkers and metal bioaccumulation in native fish captured in the Ilha River, southern Brazil. Chemosphere. 2017; 189:609-18.

23. Shinn C, Dauba F, Grenouillet G, Guenard G, Lek S. Temporal variation of heavy metal contamination in fish of the river lot in southern France. Ecotoxicol Environ Safe. 2009; 72:1957-65.

24. ANVISA - Agência Nacional de Vigilância Sanitária. Portaria ํㅡ 685, de 27 de agosto de 1998. [acesso em 2016 out 21]. Available from: http://www.anvisa.gov.br/alimentos/legis/especifica/contaminantes.htm.

25. ANVISA - Agência Nacional de Vigilância Sanitária. Resolução RDC nำ 42, de 29 de agosto de 2013. [acesso em 2016 nov 17] Available from: http://www.abic.com.br/publique/media/RDC42-2013-Contaminantes/norganicos.pdf.

26. Callegari-Jacques SM. Bioestatística: princípios e aplicações. Porto Alegre: Artmed; 2003. 255 p.

27. Bervoets L, Blust R. Metal concentrations in water, sediment and gudgeon (Gobio gobio) from a pollution gradient: relationship with fish condition factor. Environ Pollut. 2003; 126:9-19.

28. Gomiero LM, Braga FMS. The condition factor of fishes from two river basins in São Paulo state, Southeast of Brazil. Acta Scient Biol Sci. 2005;27(1):73-8.

29. Plano de Bacia do Rio Caí - Relatório da Etapa A do Plano da Bacia Hidrográfica do Rio Caí [Internet]. [place unknown: publisher unknown]; [updated 2007; cited 17 Nov 2016]. Available from:

http://www.mediafire.com/file/wz57qwmenhnap64/PLANOCA\%C3\%8D-REA-RELAT\%C3\%93 $\mathrm{RIO}+\mathrm{FASE}+\mathrm{A}$.pdf.

30. Singh N, Srivastava A. Haematological parameters as bioindicators of insecticide exposure in teleosts. Ecotoxicol. 2010; 19:838-54.

31. Seriani R, Abessa DMS, Pereira CDS, Kirschbaum AA, Assunção A, Ranzani-Paiva MJT. Influence of seasonality and pollution on the hematological parameters of the estuarine fish Centropomus parallelus. Braz J Oceanogr. 2013; 61:105-11.

32. Barisic J, Dragun Z, Ramani S, Marijic VF, Krasnici N, Coz-Rakovac R, Kostov V, Rebok K, Jardanova M. Evaluation of histopathological alterations in the gills of Vardar chub (Squalius vardarensis Karaman) as an indicator of river pollution. Ecotoxicol Environ Safe. 2015; 118:158-66. 
33. Marcato ACC, Yabuki AT, Fontanetti CS. Nickel exposure promotes osmoregulatory disturbances in Oreochromis niloticus gills: histopathological and energy dispersive spectrometry analysis. Environ Sci Pollut Res Int. 2014; 21:13095-102.

34. Procópio MS, Ribeiro HJ, Pereira LA, Lopes GAO, Castro ACS, Rizzo E, Sato Y, Russo RC, Junior JDC. Sex-response differences of immunological and histopathological biomarkers in gill of Prochilodus argenteus from a polluted river in southeast Brazil. Fish Shell Immunol. 2014;39(1):108-17.

35. Saha R, Nandi R, Saha B. Sources and toxicity of hexavalent chromium. J Coord Chem. 2011;64(10):1782-806.

36. Vieira CED, Costa PG, Lunardelli B, Oliveira LF, Cabrera LC, Risso WE, Primel EG, Meletti PC, Fillmann G, Martinez CBR. Multiple biomarker responses in Prochilodus lineatus subjected to short-term in situ exposure to streams from agricultural areas in Southern Brazil. Sci Total Environ. 2016; 542:44-56.

37. Costa SC, Hartz SM. Evaluation of trace metals (cadmium, chromium, copper and zinc) in tissues of a commercially important fish (Leporinus obtusidens) from Guaíba Lake, Southern Brazil. Braz Arch Biol Technol. 2009;52(1):241-50.

38. Zayed MA, El-Dien FAN, Rabie KA. Comparative study of seasonal variation in metal concentration in River Nile sediment, fish and water by atomic absorption spectrometry. Microchem J. 1994; 49:27-35.

39. Merciai R, Guasch H, Kumar A, Sabater S, García-Berthou E. Trace metal concentration and fish size: Variation among fish species in a Mediterranean river. Ecotoxicol Environ Safe. 2014; 107:154-61.

40. Djikanovic V, Skoric S, Jaric I, Lenhardt M. Age-specific metal and accumulation patterns in different tissue of nase (Chodrostoma nasus) from the Medjuvrsje Reservoir. Sci Total Environ. 2016;566-567:185-90.

41. Chapman D. Water quality assessments - a guide to use of biota, sediments and water in environmental monitoring. Cambridge: UNESCO/WHO/UNEP; 1992. $651 \mathrm{p}$.

42. Legret $M$, Pagotto $C$. Evaluation of pollutant loadings in the runoff waters from a major rural highway. Sci Total Environ. 1999; 235:143-50.

43. Polard T, Jean S, Merlina G, Laplanche C, Pinelli E, Gauthier L. Giemsa versus acridine orange staining in the fish micronucleus assay and validation for use in water quality monitoring. Ecotoxicol Environ Safe. 2011; 74:144-9.

(c) 2018 by the authors. Submitted for possible open access publication under the terms and conditions of the Creative Commons Attribution (CC BY NC) license (https://creativecommons.org/licenses/by-nc/4.0/). 